\title{
Analisis Inkonsistensi Penggunaan Lahan di Kawasan Lindung DAS Cisadane
}

\author{
I'anah ${ }^{1}$, Hariadi Kartodihardjo ${ }^{2}$, M.Yanuar J.Purwanto ${ }^{3}$ dan Kukuh Murtilaksono ${ }^{4}$ \\ 1Program Doktor Ilmu Pengelolaan Sumber Daya Alam dan Lingkungan, Institut Pertanian Bogor \\ ${ }^{2}$ Departemen Manajemen Hutan, Fakultas Kehutanan, Institut Pertanian Bogor \\ ${ }^{3}$ Departemen Teknik Sipil Dan Lingkungan. Institut Pertanian Bogor \\ ${ }^{4}$ Departemen Ilmu Tanah dan Sumberdaya Lahan. Fakultas Pertanian. Institut Pertanian Bogor \\ Email: ianah.prasetyo@gmail.com
}

\begin{abstract}
ABSTRAK
Kawasan lindung Daerah Aliran Sungai (DAS) berfungsi sebagai penyedia sistem pendukung kehidupan kenyataannya telah terdegradasi dan mengalami perubahan fungsi. Hal ini berpengaruh pada fungsi DAS sebagai fungsi hidrologi. Penelitian ini bermaksud untuk menganalisis kesesuaian pemanfaatan kawasan lindung dengan rencana pola ruang dan menganalisis faktor-faktor yang mempengaruhinya untuk selanjutanya dapat merumuskan arahan pengendalian serta strategi kebijakan dalam pemanfaatan ruang di kawasan lindung DAS Cisadane Kabupaten Bogor. Data dikumpulkan melalui peta tematik, penginderaan jauh dan pengamatan langsung. Analisis data didasarkan pada hasil overlay dan analisis persentase penyimpangan. Analisis spasial dilakukan untuk memperoleh informasi tentang penggunaan lahan, kepemilikan lahan, izin lokasi, dan evaluasi penggunaan lahan terhadap rencana pola ruang. Metode kualitatif melalui wawancara untuk mengidentifikasi faktor-faktor yang mempengaruhi inkonsistensi penggunaan lahan terhadap rencana pola ruang melalui tumpang susun peta RTRW 2016-2036 dengan tutupan lahan 2016. Perumusan arahan pengendalian pemanfaatan ruang diperoleh dengan analisis deskriptif. Hasil penelitian menunjukkan bahwa ketidaksesuaian pemanfaatan lahan sebesar $22.7 \%$, luas kawasan hutan yang tutupan hutan $25.35 \%$. Faktor-faktor yang menyebabkan inkonsistensi karena ketidakpahaman masyarakat tentang rencana pola ruang kawasan lindung terutama yang bukan kawasan hutan, penegakan hukum yang lemah bagi pelanggaran ruang, kurangnya koordinasi dan transparansi dalam proses perizinan, kebutuhan lahan masyarakat sekitar hutan, Perubahan budaya bertani yang menurun dan fasilitas pertanian yang kurang mendukung dan berpindahnya kepemilikan lahan. Berdasarkan aspek kelembagaan masih lemahnya Pemerintah daerah dalam mengimplementasikan perencanaan yang telah disusun. Oleh karena itu diperlukan instrument pengendalian melalui Transparansi, koordinasi dan integrasi dalam hal perizinan, RDTR perlu segera diselesaikan, pemberian insentif dan disinsentif, dan sanksi, menumbuhkan aksi bersama dalam melakukan pengawasan dan pengendalian pemanfaatan ruang.
\end{abstract}

Kata kunci: Kawasan Lindung, Rencana Pola Ruang, Inkonsistensi, Kebijakan Pengendalian, DAS Cisadane

\begin{abstract}
The watershed protection area (DAS) functions as a provider of life support system whose reality has been degraded and is changing its function. This affects the function of the watershed as a hydrological function. This study intends to analyze the suitability of the use of protected areas with satial pattern plans and analyze the factors that influence them to further formulate a direction for control and policy strategies in the use of space in Cisadane watershed protected areas in Bogor Regency. Datais collected through thematic maps, remote sensing, and direct observation. Data analysis is based on overlay result and percentage deviation analysis. Spatial analysis is carried out to obtain information about land use, land ownership, location permits, and evaluation of land use on spatial plans. Qualitative methods through interview to identify factors that influence land use inconsistencies in spatial use control directions is obtained through descriptive analysis. The results showed that the land use mismatch was $22.7 \%$, the total area of the forest that covered the forest was $25.35 \%$. factors that cause inconsistency due to community insecurity about the planned spatial pattern of protected areas, especially those that are not forest areas, weak law enforcement for space violations, lack of coordination and transparency in the licensing process, the need for community land around forests, changes in farming culture is declining and agricultural facilities that do not support and transfer land ownership. Based on the institutional aspect, the local government is still weak in implementing the plans that have been prepared. Therefore, instrument control is needed through transparency, coordination, and integration in terms of licensing, RDTR needs to be resolved immediately, giving incentives and disincentives, and sanctions, to foster joint action in conducting supervision and control of soatial use.
\end{abstract}

Keywords: Protected Areas, Spatial Pattern Plans, Inconsistencies, Control Policies, Cisadane Watershed

Citation: I'anah, Kartodihardjo, H., Purwanto, M. Y. J., dan Murtilaksono, K. (2019). Analisis Inkonsistensi Penggunaan Lahan Kawasan Lindung DAS Cisadane. Jurnal Ilmu Lingkungan, 17(3),416-424, doi:10.14710/jil.17.3.416-424 


\section{Pendahuluan}

Penggunaan lahan di Kabupaten Bogor mengalami perubahan dari waktu ke waktu untuk pemenuhan kebutuhan pembangunan dan ekonomi masyarakat (AC et al 2017; Trimarwanti 2014). Perubahan penggunaan lahan adalah suatu proses dimana aktivitas manusia mengubah bentang alam, merujuk pada bagaimana tanah telah digunakan, biasanya menekankan peran fungsional tanah untuk kegiatan ekonomi (Paul and Rasyid. 2017). Permasalahan penggunaan lahan yang terjadi setiap tahunnya menunjukan bahwa rencana penggunaan lahan tidak dilakukan dengan baik.

Penyumbang PDRB terbesar di Kabupaten Bogor yaitu sektor industri pengolahan $75.29 \%$; Perdagangan dan Eceran, Reparasi Mobil dan Sepeda Motor 18.78\%; dan Konstruksi 11.59\% (BPS Kabupaten Bogor 2017), ketiga sektor tersebut memerlukan alokasi lahan yang cukup besar untuk menjalankan aktivitanya. Kabupaten Bogor merupakan kabupaten dengan jumlah penduduk yang besar. Berdasarkan sensus penduduk tahun 2010 jumlah penduduk di DAS Cisadane yaitu 3.49 juta jiwa dengan laju pertumbuhan penduduk $3.16 \%$, sebaran tertingga berada di sub DAS Cisadane Tengah yaitu sebesar $39.80 \%$ dan sub DAS Cisadane Hulu sebesar $30 \%$. Konsekuensi dari perkembangan pembangunan, pertumbuhan ekonomi dan pengembangan wilayah menyebabkan peningkatan kebutuhan akan terus meningkat yang mendorong peningkatan fungsi lahan (Roy 2017).

Upaya pemenuhan kebutuhan lahan dapat dilakukan diantaranya dengan pembukaan lahan hutan, alih fungsi hutan, dan pembukaan lahan baru. Permasalahan penggunaan lahan akan muncul apabila penggunaan lahan yang tidak direncanakan dengan baik. Kabupaten Bogor sebagai kawasan konservasi tetapi tetapi perubahan pemanfaatan ruang, kegiatan sosial ekonomi dan kelembagaan telah berjalan secara dinamis (Fajarini et al. 2015).

Kerusakan DAS telah terjadinya erosi tanah, sedimentasi sungai, fluktuasi debit sungai dan menurunnya produktivitas lahan akibat dari kerusakan lingkungan (Sinukaban 2007). Pemanfaatan lahan tanah dan air semestinya harus berasaskan pada pembangunan berkelanjutan. Pengembangan dan penggunaan lahan yang berkaitan dengan pemanfaatan sumberdaya lahan perlu direncanakan secara tepat dan terarah dalam satuan daerah aliran sungai (DAS) dalam rangka pencegahan degradasi lahan.

Rencana Tata Ruang Wilayah Kabupaten (RTRWK) adalah sebagai salah satu institusi/kelembagaan yang mengatur perencanaan penggunaan lahan dan pemanfaat sumber daya alam di tingkat kabupaten. RTRWK sebagai institusi seharusnya mampu mengarahkan prilaku aktor dalam memanfaatkan ruang sumber daya alam secara berkelanjutan (Roy et al 2017).Tetapi institusi ini belum mampu mengatasi permasalahan lingkungan terutama ruang DAS sebagai commom pool resouces (CPRs) (Kartodihardjo 2004) tidak serta merta hilang dengan adanya RTRWK. RTRW dan mekanisme perizinan sebagai salah satu perangkat kelembagaan dalam pengendalian pemanfaatan ruang untuk menekan konversi lahan (Bakar 2008),

Perencanaan tata ruang baik di tingkat nasional, provinsi dan kabupaten semestinya harus memperhatikan kelestarian untuk keberlanjutan lingkungan. Undang-undang No 26 tahun 2007 tentang Penataan Ruang juga telah menegaskan bahwa selain Kawasan budidaya juga ada penetapan kawasan lindung. Pemerintah Provinsi Jawa Barat telah menetapkan Kawasan lindung sebesar $45 \%$ dari luas wilayah Jawa Barat. Dalam Keputusan Presiden nomor 32 tahun 1990 menjelaskan tentang Pengelolaan Kawasan Lindung secara khusus digunakan sebagai pedoman pengelolaan kawasan lindung di dalam pengembangan pola tata ruang wilayah.

Permasalahan utama dalam penataan ruang adalah sulitnya pengendalian tata ruang hal Ini dikarenakan kuranya informasi yang akurat (Jazuli 2017). Sehingga akan menyulitkan dalam menjamin kelestarian kawasan lindung. Oleh karena itu diperlukan sistem pemantauan secara berkala, sehingga kondisi eksisting mengenai perubahan apa yang terjadi di dalam kawasan lindung dapat diketahui dan dapat dijadikan dasar dalam pengambilan kebijakan terkait dengan pengelolaan kawasan lindung.

Pemanfaatan Kawasan lindung yang tidak sesuai dengan RTRW akan memberikan dampak pada fungsi Kawasan lindung dan mengancam keberlanjutan sumberdaya (Kurnianti, 2015). Menurut Dani (2017) bahwa penggunaan lahan di Kabupaten Bogor secara eksisting 51,33\% belum terlaksana sesuai RTRW sehingga bisa diarahkan agar sesuai dengan rencana pola ruang, sedangkan $38,06 \%$ penggunaan lahannya sesuai dan $10,62 \%$ tidak sesuai. Permasalahan penggunaan lahan muncul setiap tahunnya karena penggunaan lahan yang tidak direncanakan dengan baik (Junef 2016). Permasalahan degaradasi lahan akan berdampak pada meningkatnya luas lahan kritis, erosi dan banjir akan sering terjadi yang berakibat menurunnya daya dukung Daerah Aliran Sungai (Zamroh 2014). Penggunaan Kawasan lindung yang tidak sesuai dengan RTRW menunjukkan bahwa pemanfaatan lahan di Kabupaten Bogor harus dikendalikan. Salah satu instrument pengendaliannya melalui perizinan pemerintah dalam melindungi penggunaan lahan sawah (Dewi 2011; Mansur 2015).

Tujuan utama penelitian ini menanalisis kesesuaian penggunaan lahan kawasan lindung DAS Cisadane terhadap rencana pola ruang Kabupaten Bogor dan mengidentifikasi faktor-faktor yang mempengaruhi inkonsistensi penggunaan lahan terhadap rencana pola ruang di Kawasan Lindung DAS Cisadane Kabupaten Bogor. 


\section{Metode Penelitian}

\subsection{Lokasi dan Waktu Penelitian}

Penelitian ini dilakukan di Kawasan Lindung DAS Cisadane Wilayah Kabupaten Bogor. Waktu penelitian dilakukan dari Maret 2017 sampai dengan Oktober 2018. DAS Cisadane berada pada pada $6^{\circ} 72^{\prime}$ sampai 60 76' LS dan $106^{\circ} 58^{\prime}$ sampai $106^{\circ} 51^{\prime} \mathrm{BT}$. Sub DAS bagian hulu (Cianten dan Cisadane Hulu) dan sub DAS bagian tengah. Wilayah studi penelitian berada di Kawasan lindung DAS Cisadane yang meliputi beberapa Kecamatan di Kabupaten Bogor yaitu Pamijahan, Tenjoloya, Megamendung, Ciawi, Taman Sari, Caringin, Cijeruk, Sukajaya, Nanggung, Cigudeg, Rumpin, Ranca Bungur, Kemang, Ciseeng, Parung, dan Gunung Sindur, Ciampea, Dramaga, Ciomas, Cigombong, Nanggung, Leuwisadeng, Leuwiliang, dan Cibungbulang

\subsection{Metode Analisa Data}

Metode yang digunaka pada penelitian ini ada metode campuran (mixed methods research). Penelitian ini dimulai pada pengumpulan data primer dan sekunder. Metode analisis data merupakan metode campuran yang dilakukan dengan menganalisi data kuantitatif dan data kualitatif (Creswell dan Clark 2007).

Penelitian ini dilakukan melalui dua tahapan yang pertama menganalisis data kuantitatif dan yang kedua data kualitatif. Tahap pertama melalui pendekatan keruangan dengan analisis spasial dan analsisis kuantitatif, dan tahap kedua dilakukan analisis kualitatif. Pendekatan keruangan merupakan metoda analisis eksistensi ruang sebagai wadah untuk mengakomodasikan kegiatan manusia, menggunakan spatial (Yunus 2010), process analysis yang digunakan melalui analisis perubahan lahan, evaluasi kesesuaian pola ruang RTRWK dengan kondisi eksisting penggunaan lahan di dalam kawasan lindung. Hasil analisis spasial, dijelaskan secara deskritif berkaitan dengan perencanaan ruang (RTRW Kabupaten Bogor tahun 2016-2036, pemanfaatan ruang tahun 2016. Untuk menganalisis faktor-faktor yang mempengaruhi penyimpangan penggunaan lahan terhadap rencana pola ruang dilakukan melalui wawancara lapang pada pengunaan lahan yang inkonsisten dengan rencana pola ruang. Variabel hasil wawancara dipersentasekan berdasarkan frekuensi masingmasing variabel terhadap keseluruhan jumlah responden. Penelitian kualitatif diperoleh dari data data yang dikumpulkan secara wawancara, observasi, dan sebagainya (Prastowo 2012).

\section{Hasil dan Pembahasan}

3.1. Perubahan Penggunaan Lahan di Kawasan Lindung DAS Cisadane tahun 2003 dan tahun 2016.

Analisis perubahan penggunaan lahan ini untuk menganalisis perubahan penggunaan lahan tahun 2003 dan tahun 2016 di kawasan lindung DAS Cisadane. Data penutupan lahan diperoleh dari Kementerian Lingkungan Hidup dan Kehutanan (KLHK). Hasil dari analisis menunjukan bahwa kondisi penggunaan lahan di lokasi studi terdiri dari 8 kelas pennggunaan lahan utama, yaitu: hutan, perkebunan, lahan terbangun, pertambangan, pertanian lahan kering, sawah, lahan terbuka, dan tubuh air. Analisis perubahan lahan dari tahun 2003 sampai dengan tahun 2016 dianalisis menggunakan analisis join table, adapun perubahan penggunaan lahan di Kabupaten Bogor disajikan Tabel 1.

Tabel 1. Perubahan Penggunaan Lahan Tahun 2003 dan 2016

\begin{tabular}{clrrr}
\hline No & \multicolumn{1}{c}{ Kelas Penggunaan Lahan } & Luas Tahun 2003 (ha) & Luas Tahun 2016 (ha) & Perubahan (ha) \\
\hline 1 & Hutan & 25235.25 & 22861.89 & -2373.36 \\
2 & Perkebunan & 1175.18 & 2396.57 & 1221.39 \\
3 & Lahan Terbangun & 1583.43 & 2782.39 & 1198.96 \\
4 & Pertambangan & & 11.4 & 11.4 \\
5 & Pertanian Lahan Kering & 31895.4 & 32013.62 & 118.22 \\
6 & Sawah & 195.36 & 3311.06 & 3115.7 \\
7 & Lahan Terbuka & 3477.45 & 199.09 & -3278.36 \\
8 & Tubuh Air & 327.03 & 312.07 & -14.96 \\
\hline & Jumlah & 63889.52 & 63889.52 & \\
\hline
\end{tabular}

Sumber data diolah dari hasil peta tutupan lahan 2003 dan 2016

Penggunaan lahan hutan mengalami penurunan sekitar 2373.36 ha atau $3.7 \%$ dari luas kawasan lindung yang ada di DAS Cisadane, hutan mengalami degradasi rata-rata 182.55 ha/th. Kawasan hutan berubah menjadi Lahan pertanian kering 1801.11 ha sekitar $75.89 \%$ kawasan hutan menjadi pertanian lahan kering dan lahan terbangun sekitar 458.37 ha (19.3\%) dari kawasan hutan yang berubah. Degradasi kawasan hutan menjadi lahan pertanian kering dan lahan terbangun. Cukup tingginya perubahan penggunaan lahan dari hutan menjadi lahan pertanian, menunjukan bahwa sektor pertanian masih menjadi sektor utama bagi masyarakat dalam memenuhi kebutuhan hidupnya, hal ini dapat menjadi salah satu indikator sebagai tingginya tingkat ketergantungan masyarakat terhadap hutan karena keterbatasan lahan untuk kegiatan pertanian. 


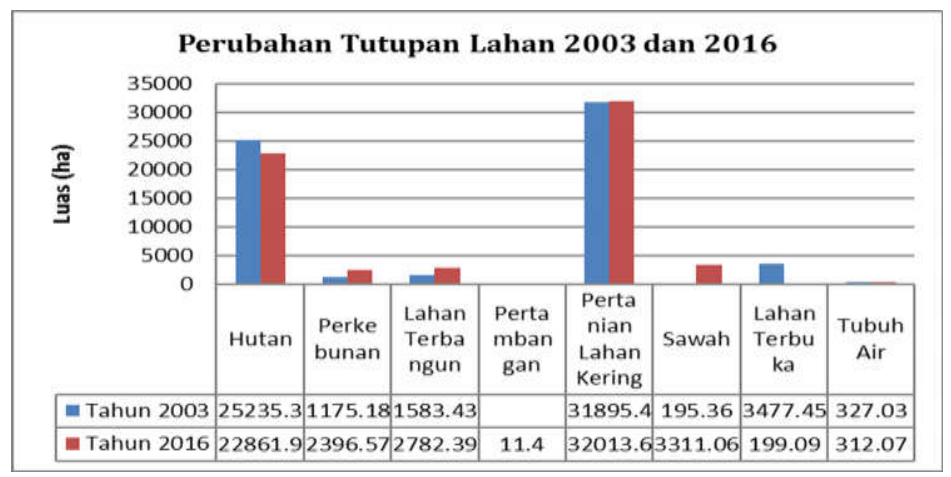

Gambar 1 Diagram Perubahan Tutupan Lahan

Keputusan Menteri Kehutanan nomor: 195/Kpts-II/2003 tanggal 4 Juli 2003 tentang penetapan Kawasan hutan di Kabupaten Bogor berupa perubahan peruntukan kawasan hutan, penataan batas, dan perubahan fungsi kawasan hutan. Bherdasarkan hasil analisis menunjukan luasan kawasan hutan di kawasan lindung DAS Cisadane Kabupaten Bogor seluas ha $(42.3 \%)$ dari luas kawasan lindung DAS Cisadane. Kelas penggunaan lahan hutan yang berubah menjadi pertanian (1.801.11ha), lahan terbangun 458.37ha (19.3\%) dan lahan terbuka (151.19 ha), hal ini perlu menjadi perhatian bagi pengelola kawasan hutan dan pemerintah daerah karenan pentingya fungsi hutan dalam menjaga keberlanjutan air dan ekosistem terutama dikawasan lindung. Dampak dari perubahan lahan berupa peningkatan aliran permukaan akibat perubahan lahan yang terjadi dalam DAS (Putuhena 2013).

Perubahan penggunaan lahan dan perkembangan spasial yang tidak terkendali penyebabnya bukan kota/kabupaten tidak mempunyai konsep tata ruang, tetapi karena implikasi RTRW kalah cepat dengan perubahan spasial yang ada di lapangan (Yunus 2008). Ada empat faktor yang berpengaruh terhadap kinerja pengelolaan sumber daya alam yaitu sumber daya alam (natural capital), sumber daya manusia (human capital), sumber daya buatan manusia (man made capital) serta pranata institusi formal maupun informal masyarakat (social capital) (Kartodihardjo 2000).

\subsection{Gambaran Jenis Penggunaan Lahan, Kepemilikan Lahan, Izin Lokasi di Kawasan Lindung DAS Cisadane Wilayah Kabupaten Bogor}

Penggunaan lahan Kabupaten Bogor tahun 2016 berdasarkan urutan luasan yaitu berupa pertanian lahan kering 32103.62 (50.1\%), Hutan (35.78\%), sawah (5.18\%), lahan terbangun (4.3\%), Perkebunan (3.75\%), lahan terbuka $(0.3 \%)$, tubuh air $(0.48 \%)$, dan Pertambangan (0,02\%). Luas terbesar penggunaan lahan Pertanian Lahan Kering. Hutan didominasi oleh hutan lebat yang sebagian besar berupa hutan konservasi yang tersebar luas di bagian selatan. Hasil analisis berupa peta penggunaan lahan Kabupaten Bogor tahun 2016 seperti disajikan pada Gambar 2.

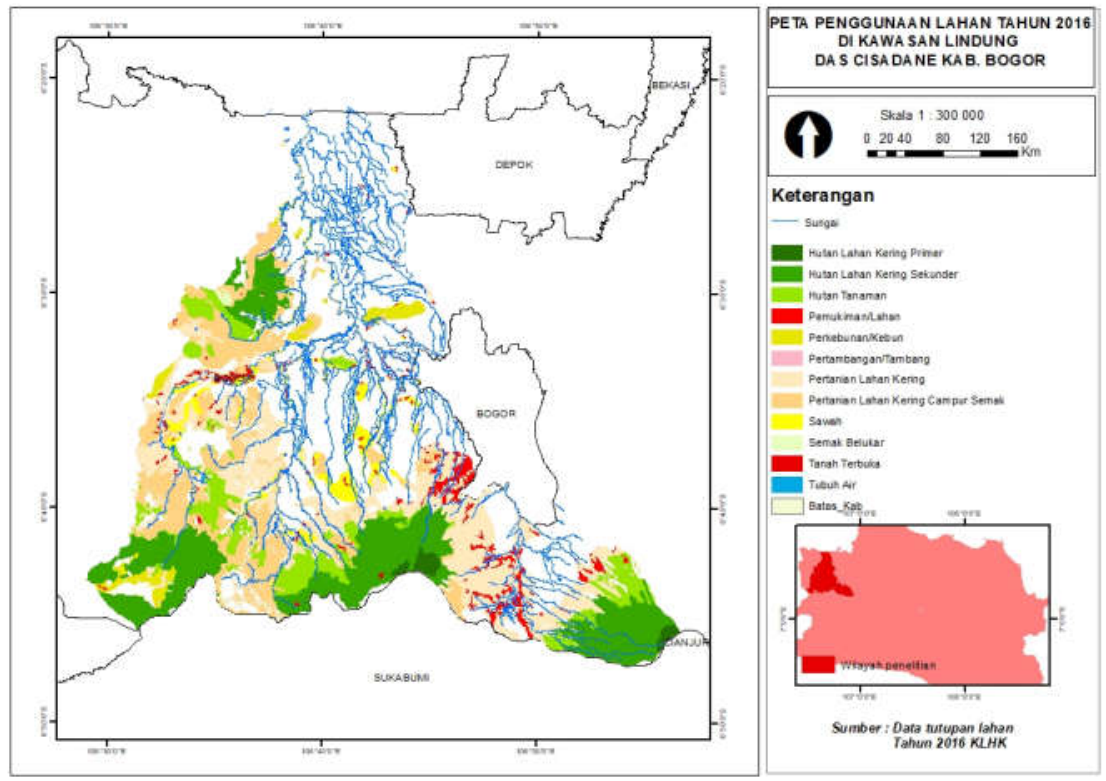

Gambar 2 Diagram Perubahan Tutupan Lahan 
- Kawasan Lindung Hutan

- Kawasan Lindung Non Hutan

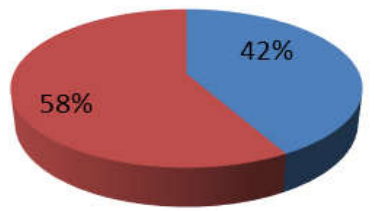

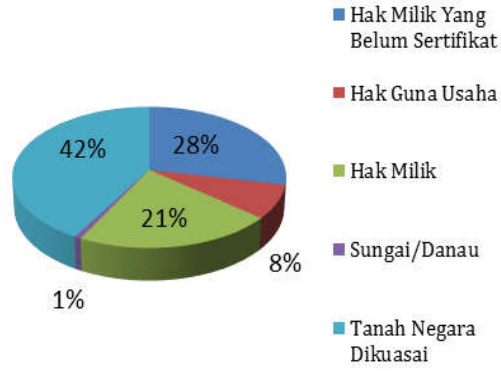

Dikuasai

Gambar 3 Kawasan Lindung dan Hasil Analisis Kepemilikan Lahan

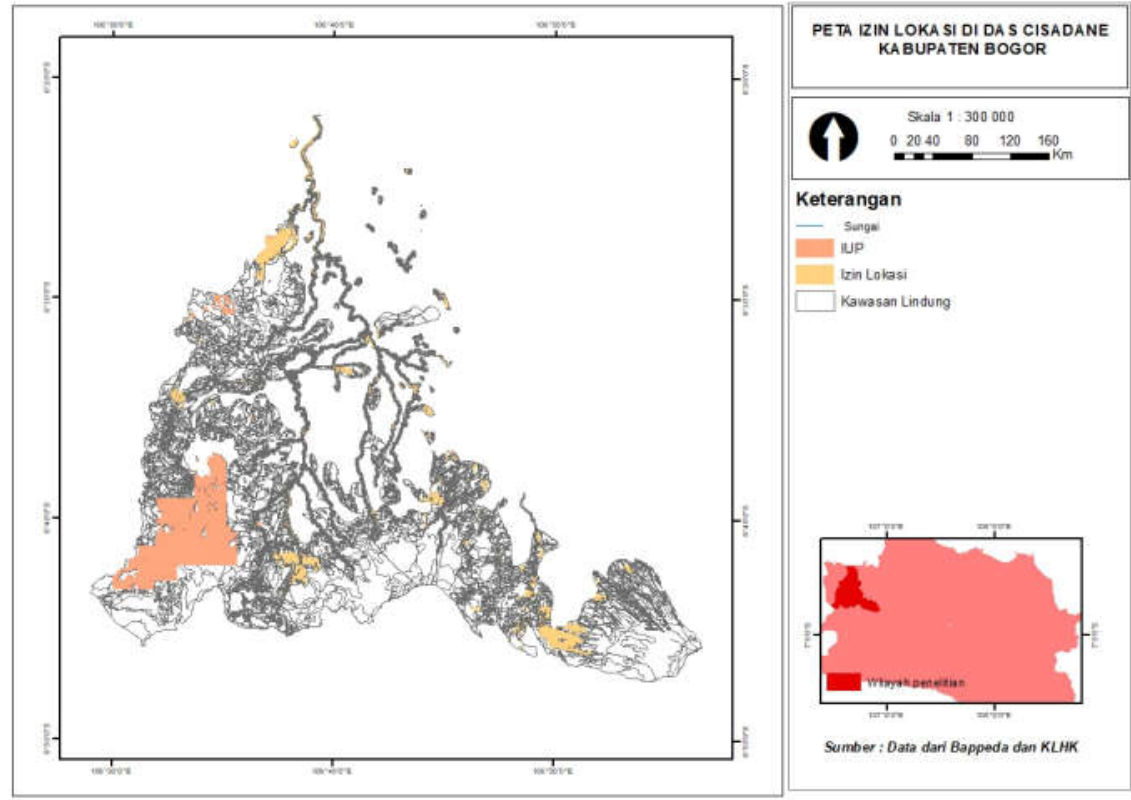

Gambar 4 Peta Izin Lokasi di DAS Cisadane Kabupaten Bogor

Luas area izin lokasi Kabupaten Bogor dari tahun 2000-2015 di kawasan non hutan adalah 1.626,57 ha atau sekitar 3\% dari keseluruhan luas kawasan lindung. Berdasarkan luas peruntukannya diurutkan sebagai berikut: perumahan (77.95\%), bisnis dan usaha perekonomian $(0.48 \%)$, wisata $(18.11 \%)$ dan pertambangan (3.06\%), ijin pertambangan dikawasan hutan $10.12 \%$ baik itu dihutan konservasi maupun hutan produksi, seperti disajikan pada Gambar 4. Berbagai kegiatan di DAS Cisadane bagian hulu untuk pemukiman, wisata, pertambangan dan industry menyebabkan adanya perbedaan tingkat kepentingan dan pengaruh antar aktor yang terlibat didialmnya dapat menjadi sumber konflik dalam pengelolaan suatu wilayah, karena masing-masing aktor berusaha memanfaatkan kekuasaan yang dimiliki untuk mendapatkan kepentingannya (Febriyanto 2014).

\subsection{Evaluasi Kesesuaian Penggunaan Lahan ter- hadap Rencana Pola Ruang}

Hasil analisis tumpang susun peta penggunaan lahan dengan peta rencana pola ruang (Tabel 2 dan Gambar 5) adalah kawasan hutan berdasarkan 420
RTRW 2016-2036 26.286,99 ha tetapi seluas $10.122,68$ ha $(38.47 \%)$ sudah tidak berhutan lagi. Kawasan hutan yang sudah tidak berhutan didiominasi oleh lahan pertanian kering 8.599,37ha. Kawasan perkebunan seluas $17.652,21$ ha sebagian besar dimanfaatakan untuk pertanian lahan kering seluas 10.161.22 ha (57.5\%) dari lahan yang dilalokasikan untuk perkebunan 11.4 ha untuk lahan pertambangan, Kawasan pertanian seluas 21.348,19 ha digunakan untuk pemukiman seluas $1.178,55$ ha (5.52\%). Luas tutupan hutan di kawasan hutan hanya $16.164,26$ ha $(61.49 \%)$ yang berhutan. Sementara itu, rencana luas kawasan pertanian lahan basah, kawasan pertanian lahan kering, dan kawasan perkebunan sudah terpenuhi dari luas penggunaan eksisting, sedangkan penggunaan lahan eksisting berupa lahan terbuka dapat dialihkan untuk penggunaan lain yang luasannya belum terpenuhi.

Dari Tabel 2 diperoleh hasil penggunaan lahan yang sesuai dengan rencana pola ruang seluas 14.813 .95 ha $(23.18 \%)$, sedangkan penggunaan lahan yang tidak sesuai seluas 14.506,26 ha (22.7\%), sisanya belum terlaksana dan penggunaan lahan masih dapat berubah sesuai dengan rencana pola 
ruang seluas 34.569 .31 ha $\quad(54,07 \%)$. Luas inkonsistensi penggunaan lahan tertinggi terdapat pada kawasan hutan. Berdasarkan RTRW 2016-2036 alokasi kawasan hutan 26.286,99ha akan tetapi tutupan hutan yang berada dikawasan hutan hanya 20.569.03 ha (78.24\%). Inkonsistensi sebesar $21.75 \%$. Peta kesesuaian penggunaan lahan terhadap rencana pola ruang seperti pada Gambar 5. Inkonsistensi penggunaan lahan di kawasan lindung terhadap RTRW dikhawatirkan dapat menurunkan kemampuan fisik lahan tersebut serta dapat mengancam keberlanjutan sumberdaya (Kunianti 2015)

Tabel 2. Hasil Analisis Tumpang Susun Penggunaan Lahan terhadap Rencana Pola Ruang

\begin{tabular}{|c|c|c|c|c|c|c|c|c|c|}
\hline \multirow[b]{2}{*}{$\begin{array}{l}\text { Pola Ruang RTRW 2016- } \\
2036\end{array}$} & \multicolumn{8}{|c|}{ Tutupan Lahan 2016} & \multirow[t]{2}{*}{ Jumlah } \\
\hline & Hutan & $\begin{array}{c}\text { Lahan } \\
\text { Terbangu } \\
\mathrm{n}\end{array}$ & $\begin{array}{l}\text { Perke- } \\
\text { bunan }\end{array}$ & $\begin{array}{l}\text { Per- } \\
\text { tamba } \\
\text { ngan }\end{array}$ & $\begin{array}{c}\text { Pertania } \\
\text { n Lahan } \\
\text { Kering }\end{array}$ & Sawah & $\begin{array}{c}\text { Lahan } \\
\text { Terbuk } \\
\text { a }\end{array}$ & $\begin{array}{l}\text { Tubuh } \\
\text { Air }\end{array}$ & \\
\hline Enclave & $593.28^{1)}$ & $36.10^{1)}$ & $914.52^{1)}$ & & $498.95^{1)}$ & & & & 2042.87 \\
\hline Kawasan Hutan & 16939.53 & & & & & & & & \\
\hline Konservasi & 1) & $34.26^{2}$ ) & $282.35^{2)}$ & & $3113.52^{2)}$ & $1.54^{2)}$ & $64.94^{2)}$ & & 20436.14 \\
\hline $\begin{array}{l}\text { Kawasan Hutan Lindung } \\
\text { Kawasan Hutan Produksi }\end{array}$ & $1122.96^{1)}$ & $1.64^{2)}$ & 0 & & $1982.81^{2)}$ & $1.59^{2)}$ & 0 & $8.65^{2)}$ & 3117.65 \\
\hline $\begin{array}{l}\text { Terbatas } \\
\text { Kawasan Hutan Produksi }\end{array}$ & $454.45^{1)}$ & & & & $361.44^{2)}$ & & $0.96^{2)}$ & & 816.86 \\
\hline $\begin{array}{l}\text { Tetap } \\
\text { Kawasan Peruntukan }\end{array}$ & $2052.09^{1)}$ & $1.55^{2)}$ & $4.69^{2)}$ & & $583.73^{3)}$ & $1.63^{3)}$ & $0.012^{3)}$ & & 2643.70 \\
\hline $\begin{array}{l}\text { Industri } \\
\text { Kawasan Peruntukan }\end{array}$ & 0.0 & $53.71^{1)}$ & 0.00 & & $139.00^{3)}$ & $\begin{array}{r}9.55^{3)} \\
2225.33^{1}\end{array}$ & & & 202.26 \\
\hline $\begin{array}{l}\text { Lahan Basah } \\
\text { Kawasan Pertanian Lahan }\end{array}$ & $217.93^{2)}$ & $266.13^{2)}$ & $18.05^{2)}$ & & $6782.42^{3)}$ & ) & & $111.25^{3)}$ & 9621.11 \\
\hline Kering & $270.89^{3)}$ & $164.53^{2)}$ & $3.66^{3)}$ & & $3903.62^{1)}$ & $101.56^{2)}$ & $131.66^{3}$ & $28.44^{2)}$ & 4472.69 \\
\hline Kawasan Perkebunan & $1171.34^{3)}$ & $68.53^{2)}$ & 797.071) & $11.40^{2)}$ & $8304.64^{2)}$ & $84.49^{2)}$ & ) & $43.89^{2)}$ & 10613.02 \\
\hline Kawasan Pemukiman & $39.41^{3)}$ & $2148.82^{11)}$ & $371.43^{3)}$ & & $6210.20^{3)}$ & $874.673)$ & $1.993)$ & $107.54^{2)}$ & 9754.06 \\
\hline Situ & & $7.13^{2)}$ & $4.81^{3)}$ & & 133.293) & $10.70^{3)}$ & $0.22^{3)}$ & $13.02^{1)}$ & 169.16 \\
\hline Jumlah & 22268.61 & 2746.29 & 1482.05 & 11.40 & 31514.66 & 3311.06 & 199.79 & 312.78 & 61846.65 \\
\hline
\end{tabular}

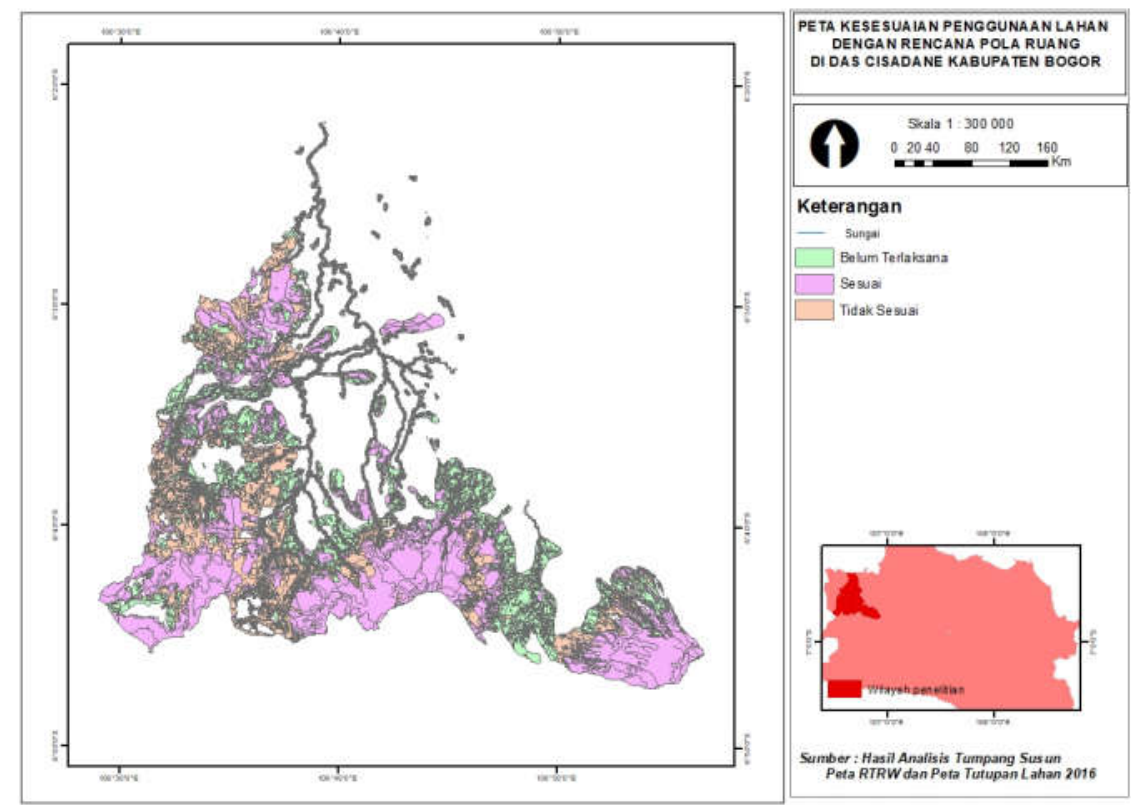

Gambar 5 Peta Kesesuaian Penggunaan Lahan Dengan Rencana Pola Ruang DAS Cisadane di Kabupaten Bogor 


\subsection{Faktor-faktor yang Mempengaruhi Inkonsistensi Penggunaan Lahan terhadap Rencana Pola Ruang}

Hasil analisis wawancara lapangan dengan masyarakat daerah hulu DAS Cisadane, Tokoh Masyarakat, kelompok tani, kepala desa dan pejabat lain serta para pemerhati lingkungan diperoleh beberapa faktor yang mempengaruhi inkonsistensi penggunaan lahan terhadap rencana pola ruang. Faktor-faktor tersebut secara berurutan yaitu : (1) Kurangnya/ tingkat pemahaman yang berbeda dari aktor dan masyarakat tentang pola ruang lindung karena kurangnya koordinasi dan sosialisasi dokumen RTRW Kabupaten Bogor (2) Lemahnya penindakan para pelanggar rencana tata ruang, pelunya koordinasi dan transparansi dalam meberikan perizinan pemanfaatan ruang. Kurang tertibnya Izin Mendirikan Bangunan (IMB) dan Surat Izin Usaha. (3) Manajemen pengelolaan kawasan lindung belum berjalan karena Koordinasi yang kurang antara instansi UPT pemerintah pusat dengan Pemda. (4) Perubahan pergeseran gaya hidup masyarkat dengan menganggap petani bukan pekerjaan yang menjanjikan, Biaya pertanian mahal dan fasilitas pertanian kurang sehingga hasil panen tidak sebanding dengan biaya. Hal ini yang mendorong masyarakatnya untuk menjual lahannya ke pemodal (4) Fasilitas umum dan aksesibilitas yang mudah berdampak pada harga tanah yang tidak bisa dikendalikan mendorong masyarakat untuk mengkonversi menjadi lahan komersiil.

Dalam upaya menanggulangi adanya inkonsistensi tersebut maka diperlukan lembaga koordinasi dan pelaksana pengawasan dan pengendalian pemanfaatan ruang seluruh sektor, hal ini dikarenakan RDTR sangat penting karena dasar hukum dari pelaksanaan rencana tata $r$ uang. Hal ini akan menyebabkan Implementasi Kebijakan RTRW akan berjalan dengan baik.

Kondisi saat ini sebenarnya prosedur perencanaan, pelaksanaan, pengawasan dan pengendalian sudah dilakukan sesuai peraturan yang ada namun tidak diikuti dengan penindakan secara tegas terhadap pelanggaran rencana tata ruาang. Lemahnya penegakan hukum dan pengendalian ini merupakan kelemahan pada aspek pelaksana. Hal yang bisa mengancam implementasi adalah investasi dan kebejikan pemerintah tentang peningkatan nilai pajak (Eko dan Rahayu 2012).

Pelanggaran terhadap pemanfaatan ruang berdasarkan survey dilapangan memang karena ketidaktahuan masyarakat terhadap rencana pemanfaatan ruang dan juga ada memang sengaja pelanggaran itu dilakukan. Kurangnya/ tidak samanya pemahaman dari aktor dan masyarakat tentang pola ruang lindung karena kurangnya koordinasi dan sosialisasi. Beberapa aktor yang terlibat dalam perencanaan maupun pemanfaatan ruang memiliki pemahaman yang tidak sama begitu juga di masyarakat. Pemahaman Kawasan lindung hanya sebatas hutan lindung dan hutan konservasi 422 milik negara. Kurangnya sosialisasi dari Perda RTRW Kabupaten juga mempengaruhi pengetahuan masyarakat tentang Kawasan dan fungsi lindung. Kurangnya pengetahuan ini tentunya akan berpengaruh pada partisipasi masyarakat dalam menjaga Kawasan lindung Perijinan merupakan hal yang penting dalam mengendalikan pemanfaatan ruang untuk lebih terarah pada kebijakan rencana tata ruang.

Bukti di lapangan tidak ada insentif bagi pemilik lahan kawasan lindung pada DAS Cisadane untuk mengelola lahan bertutupan hutan secara berkelanjutan. Kebijakan yang mengatur secara jelas pemberian ganti rugi/kompensasai areal budidaya/lahan milik yang dirubah menjadi kawasan lindung tidak ada. Hal ini menyebabkan menyebabkan pemilik lahan merasa dirugikan akibat adanya pengaturan tata ruang. Kerugian akibat rencana tata ruang seharusnya ada kompensasi yang diberikan. Prosedur penentuan, bentuk dan perhitungan besarnya kompensasi perlu dituangkan dalam kebijaksanaan pemerintah dalam bentuk peraturan perundang-undangan.

\subsection{Arahan Pengendalian Pemanfaatan Ruang}

Konsistensi pemanfaatan ruang terhadapt implementasi kebijakan pemanfaatan ruang menjadi tanggung jawab pemerintah dalam pengendalian pemanfaatan ruang. Pemerintah bertanggung jawab meningkatkan kesejahteraan masyarakat, mewujudkan keadilan, mengurangi konflik dan dampak negatif penataan ruang serta menjamin berlangsungnya pembangunan yang efisien, efektif serta sesuai dengan fungsi dan konsisten dengan RTRW (Kartika, 2011).

Dengan melihat faktor-faktor penyebab ketidaksesuaian pemanfaatan ruang lindung, maka strategi dan arahan dalam pengendalian pemanfaatan Kawasan lindung DAS dapat melalui :

1) Penyamaan pemahan Bersama mengenai Kawasan lindung dan RTRW sebagai dokumen perencanaan tata ruang daerah yang memiliki kekuatan hukum sebagai acuan dan pedoman keruangan semua instansi Pemda. Perlunya peningkatan koordinasi dan komunikasi yang intensif antar pemerintah daerah itu sendiri dan pemerintah pusat. Pentingnya sosialisasi kepada Masyarakat sebagai obyek dalam penyusunan dan implementasi RTRW. Melakukan sosialisasi dokumen RTRW kepada semua pihak. 2) Pemberian izin yang dilakukan pemerintah pusat maupun daerah harus transparan dan terkoordinasikan dengan instansi lain. Pengawasan, monitoring dan evaluasi secara berjenjang dan berkala yang didukung kerjasama yang baik dari seluruh pihak baik dari pemerintah, masyarakat, swasta, maupun stakeholders lainnya dengan menumbuhkan aksi bersama dalam melakukan pengawasan dan pengendalian pemanfaatan ruang. Penggunaan lahan yang tidak sesuai terutama di kawasan lindung perlu diberi peringatan dan diarahkan untuk memanfaatkan 
ruang sesuai rencana pola ruang. Jika tidak dilaksanakan maka dapat diberikan sanksi administratif, denda, kenaikan pajak atau pembongkaran bangunan (jika berupa lahan terbangun). Bagi Kawasan lindung yang sudah terlanjur rusak perlu direhabilitasi. 3) Perlunya instansi/Lembaga yang bertanggung jawan dalam pengelolaan kawasan lindung non hutan dan adanya koordinasi antara Pemda dan UPT pemerintah pusat untuk mengelola kawasan lindung yang baik. 4) Rencana Detail Tata Ruang dan peraturan terkait dengan hak dan kewajiban pemilik lahan yang berada dikawasan lindung baik yang berada dalam kawasan hutan maupun di luar kawasan hutan perlu ditetapkan bersama. 5) Pemberian insentif dan disinsentif, Pemerintah perlu memberikan kompensasi/insentif bagi pemilik lahan yang lahannya memiliki fungsi kawasan lindung. kompensasi/insentif yang diberikan. Selain kompensasi finansial perlu kompensasi non finansial sehingga diharapkan pada akhir secara bertahap kompensasi berupa uang dapat dihapuskan menjadi hak pengelolaan sesuai ketentuan untuk pengelolaan kawasan lindung.: Insentif diberikan bagi pemilik lahan yang merelakan lahannya untuk fungsi lindung sesuai dengan pola ruang yang direncanakan, Insentif bisa berbentu bantuan, sarana prasarana wilayah, untuk dan fasilitas penunjang pertanian, memberikan kemudahan perizinan, , serta keringanan pajak bagi pemanfaatan ruang yang sejalan dengan rencana pola ruang, Disinsentif diberikan bagi pelanggar pemanfaat ruang yang tidak sesuai rencana pola ruang disinsentif berupa tidak boleh dikembangkan luasan maupun bangunannya (jika berupa lahan terbangun).

\section{KESIMPULAN}

Rencana Pola Ruang di Kawasan Lindung DAS Cisadane terdiri dari kawasan hutan, Perkebunan, Pertanian Lahan Kering, Pertanian Lahan Basah, Kawasan Industri dan Situ. Kawasan lindung DAS Cisadane 42\% merupakan kawasan hutan dan 58\% merupakan kawasan nonhutan. Penggunaan lahan yang dominan yaitu Pertanian Lahan Kering dan Hutan. Luas tutupan hutan di kawasan hutan hanya $16.164,26$ ha $(25.35 \%)$ dari luas kawasan lindung DAS. Berdasarkan UU no. 26 tahun 2007 luas tutupan hutan minimal 30\% dari luasan DAS yang ada. Izin lokasi didominasi untuk peruntukan perumahan, bisnis dan usaha ekonomi, dan agrowisata. Sebagian besar penggunaan lahan sudah sesuai dengan pola ruang, baik yang berupa penggunaan lahan eksisting maupun yang masih belum terlaksana, sedangkan penggunaan lahan eksisting yang tidak sesuai sebesar $22.7 \%$ hal ini perlu menjadi perhatian para pengelolaa di kawasan lindung DAS baik itu pemerintah daerah, pemerintah pusat maupun kementerian sektor lain seperti Kementerian Lingkungan Hidup dan Kehutanan (KLHK) maupun kementerian lainnya.
Beberapa hal yang mempengaruhi inkonsistensi penggunaan lahan terhadap rencana pola ruang terkait kurangnya pengetahuan masyarakat tentang rencana pola ruang karena kurangnya sosialisasi kepada masyarakat, penegakan hukum, perubahan budaya bertani yang kurang diminati, transparansi perizinan, kebutuhan lahan, fasilitas umum dan aksesibilitas. Arahan pengendalian pemanfaatan melalui beberapa instrument yaitu penegakan hukum, insentif dan disinsentif, transpranasi perizinan sebagai pengendalin ruang dan peraturan zonasi. Sosialisasi kebijakan dan Pengawasan, monitoring dan evaluasi melalui lembaga koordinasi yang terintegrasi antar sektor.

\section{DAFTAR PUSTAKA}

AC, MR., Rusidana, O., dan Ichwandi, I. 2017. Dinamika Perubahan Dan Kebijakan Pemanfaatan Ruang Di Kabupaten Bogor, Provinsi Jawa Barat. Journal of Env. Engineering \& Waste Management . Vol. 2, No. 2, Oktober 2017: 60-68.

Bakar, S. (2008) Kelembagaan Pengendalian Pemanfaatan Ruang di Daerah. Buletin Online Tata Ruang, MeiJuni 2008. Diperoleh dari http://penataanruang.pu.go.id/bulletin/_ pada tanggal 4 April 2016.

[BPS] Badan Pusat Statistik. 2016. Kota Bogor Dalam Angka. Bogor (ID): BPS Kota Bogor.

Eko T dan Rahayu S. 2012. Perubahan Penggunaan Lahan dan Kesesuaiannya terhadap RDTR di Wilayah Peri-Urban Studi Kasus: Kecamatan Mlati. Jurnal Pembangunan Wilayah dan Kota. Biro Penerbit Planologi Undip

Volume 8 (4): 330-340 Desember 2012.

Creswell, John W. 2010 Edisi ke-3. Research Design Pendekatan Kualitatif, Kuantitatif, dan Mixed. Yogyakarta :

Dani ET, Sitorus STP, Munibah K. 2016. Analisis Penggunaan Lahan dan Arahan Pengendalian Pemanfaatan Ruang di Kabupaten Bogor. Jurnal Tata Loka Volume 19 Nomor 1, Februari 2017, 4052

Dewi, W.S., dan Suwardi (Ed.) (2011) Prosiding Seminar dan Kongres Nasional Himpunan Ilmu Tanah Indonesia X (Tanah Untuk Kehidupan yang Berkualitas) ; 6-8 Desember 2011; Surakarta, Indonesia, hlm. 554-561. Surakarta: Jurusan Ilmu Tanah, Fakultas Pertanian, Universitas Sebelas Maret Surakarta dan Himpunan Ilmu Tanah Indonesia.

Dewi, I.A. (2011) Efektifitas Tata Ruang sebagai Instrumen Pengendalian Perubahan Penggunaan Tanah Sawah menjadi Penggunaan Non Pertanian di Kabupaten Bekasi. Dlm: Ariyanto, D.P., Dewi, W.S., dan Suwardi (Ed.) (2011) Prosiding Seminar dan Kongres Nasional Himpunan Ilmu Tanah Indonesia X (Tanah Untuk Kehidupan yang Berkualitas) ; 6-8 Desember 2011; Surakarta, Indonesia, hlm 1005-1011. Surakarta: Jurusan Ilmu Tanah, Fakultas Pertanian, Universitas Sebelas Maret Surakarta dan Himpunan Ilmu Tanah Indonesia.

Fajarini, R., Barus, B., dan Panuju, D.R.. (2015) Dinamika Perubahan Penggunaan Lahan dan Prediksinya untuk Tahun 2025 serta Keterkaitannya dengan 
Perencanaan Tata Ruang 2005-2025 di Kabupaten Bogor. Jurnal Tanah dan Lingkungan 17(1), 8-15.

Febriyano, I.G. (2014). Politik ekologi pengelolaan mangrove di Kabupaten Pesawaran Provinsi Lampung. (Disertasi). Bogor: Institut Pertanian Bogor

Jazuli A. 2017. Penegakan Hukum Penataan Ruang Dalam Rangka Mewujudkan Pembangunan Berkelanjutan.Jurnal Rechts Vinding.Volume 6 No.2.

Kartodihardjo H, Murtilaksono K, Sudadi U. 2004. Watershed Management Institutions: Concepts and Introduction to Policy Analysis. Bogor (ID): Faculty of Forestry, Bogor Agricultural University

Kurnianti, D.N. (2015) Proyeksi Penggunaan Lahan untuk Konsistensi Tata Ruang di Kawasan Jabodetabek . Tesis, Sekolah Pascasarjana. Institut Pertanian Bogor.

Mansur, Y,H. (2015) Analisis Sosio - Agraria dan Konversi Lahan serta Strategi Perlindungan Lahan Sawah di Kota Sukabumi . Tesis, Sekolah Pascasarjana. Institut Pertanian Bogor.

Junef M. 2016. Penegakan Hukum Dalam Rangka Penataan Ruang Guna Mewujudkan Pembangunan Berkelanjutan. Jurnal Penelitian Hukum. DE JURE, ISSN 1410-5632 Vol. 17 No. 4 , Desember 2017: 373 $-390$.

Roy S. 2017. Water Allocation Plan on Part of Cisaadane Catchment in the District ang City of Bogor. Jurnal Teknik Hidraulik, Vol. 7 No. 2,Desember 2017: 195 $-210$

Mayasary, D.S. (2015) Analisis Perubahan Penggunaan Lahan, Pola Ruang dan Tingkat Perkembangan Wilayah di Kota Bogor . Skripsi, Departemen Ilmu Tanah dan Sumberdaya Lahan, Fakultas Pertanian. Institut Pertanian Bogor.
Panuju, D.R. dan Rustiadi, E. (2013) T e k n i k A n a li s i s P er enc an a a P e n ge mbangan Wil a yah. Bogor: Lab. Pengembangan Wilayah, Departemen Ilmu Tanah dan Sumberdaya Lahan, Institut Pertanian Bogor.

Paul BK, Rasyid H.2017. Landuse Change and Coastal Management. Journal and book ScinceDirect. https://doi.org/10.1016/B978-0-12-8052761.00006-5

[Pemda. Kab. Bogor] Pemerintah Daerah Kabupaten Bogor (2016) Website Resmi Kabupaten Bogor. Diperoleh dari https://bogorkab.go.id pada tanggal 4 April 2016.

Putuhena JD. 2013. Model dinamik pengelolaan daerah aliran sungai (watershed) dalam upaya penyediaan air yang berkelanjutan di Semenanjung Leitimor Pulau Ambon [disertasi]. Bogor (ID): Institut Pertanian Bogor

Sinukaban, 2007. Pembangunan Daerah Berbasis Strategi Pengelolaan DAS. Makalah pada Semiloka Pengelolaan DAS“Pembangunan Daerah Berbasis Pengelolaan Daerah Sungai", Lampung 13 Desember.

Trimarmanti E.2014. Evaluasi Perubahan Penggunaan Lahan Kecamatan di Daerah Aliran Sungai Cisadane Kabupaten Bogor. Jurnal Wilayah dan Lingkungan 2(1).

Yunus, Hadi Sabari. 2008. Dinamika Wilayah Peri-Urban: Deterninan Masa Depan Kota. Yogyakarta: Pustaka Pelajar.

Zamroh AMR. 2014. Analisis Perubahan Penggunaan Lahan untuk Pemukiman di Kecamatan Kaliwungu dengan Sistem Informasi Geografis.Jurnal.Pendidikan Geografi Vol 2 no 1 Oktober 2014. 